\title{
NMDA Receptor Activation-Responsive Phosphoproteins in the Developing Optic Tectum
}

\author{
Alfred J. Scheetz and Martha Constantine-Paton \\ Department of Biology, Yale University, New Haven, Connecticut 06520
}

A front phosphorylation assay followed by two-dimensional gel electrophoresis was used to detect proteins in the tadpole optic tectum, the phosphorylation state of which is regulated by NMDA receptor activation. Five proteins with isoelectric points between 4 and 7 displayed marked increases in their phosphorylation state in response to application of $10 \mu \mathrm{M}$ glutamate and $50 \mu \mathrm{M}$ NMDA. This response was inhibited by $60 \mu \mathrm{M} 2$-amino5-phosphopentanoic acid. These proteins are termed NMDA receptor activation-responsive phosphoproteins (NARPPS). Two NARPPS were identified as both in vitro and in vivo substrates for protein kinase $C$. Of these two NARPPs, one was located in the postsynaptic density (NARPP-50), and one was located in the nuclear fraction (NARPP-21). Phosphorylation of NARPP-21 was also induced by application of the metabo- tropic glutamate receptor agonist trans-( \pm -1-amino-1,3cyclopentanedicarboxylic acid (trans-ACPD) (100 $\mu \mathrm{M}$ ). Phosphorylation of all NARPPs was eliminated by dantrolene, which inhibits release of calcium from intracellular stores. In adult tecta, only NARPP-21 and -50 were phosphorylated by $10 \mu \mathrm{M}$ glutamate and $50 \mu \mathrm{M}$ NMDA, and application of $10 \mu \mathrm{M}$ glutamate alone was sufficient to induce NARPP-21 phosphorylation. Thus the phosphorylation state of most NARPPs is regulated differently when synaptic plasticity is low. Further characterization of NARPPS should lead to identification of second messenger systems involved in NMDA receptor signaling and developmental synaptic plasticity.

Key words: synaptic plasticity; visual system; glutamate receptor; second messenger; Rana pipiens; protein phosphorylation
The NMDA subtype of glutamate receptor has been implicated in several forms of synaptic plasticity, some of which involve structural rearrangements in synaptic connections (Constantine-Paton, 1990; Constantine-Paton et al., 1990). The signal transduction events linking NMDA receptor activation to structural rearrangements are not well understood, but external signals often regulate protein function via phosphorylation, a component of many second messenger systems frequently implicated in neural plasticity. Structural plasticity is both prominent and dependent on NMDA receptor activation in the developing tadpole retinotectal projection (Cline et al., 1990). We have used this system to examine the effects of NMDA receptor stimulation on protein phosphorylation.

A fundamental characteristic of the vertebratc visual system is the topographic projection from the retina to its target structures (Udin and Fawcett, 1988). After retinal axons reach their target regions during development, an activity-dependent mechanism refines the projection to the precise point-to-point representation of the visual world that is typical of the mature pathway. This refinement is believed to occur through the temporal summation of synaptic potentials generated in a common target neuron by synapses from neighboring retinal ganglion cells with correlated firing patterns (Mastronarde, 1983a,b). This summation should remove the voltage-dependent $\mathrm{Mg}^{2+}$ block of the NMDA receptor channel (Mayer et al., 1984). Thus, NMDA receptor activation

Received Aug. 3, 1995; revised Oct. 23, 1995; accepted Nov. 30, 1995.

This research was supported by National Institutes of Health Grant RO1 EY06039 to M.C.P. and a National Research Service Award to A.J.S. We thank Dr. Eric Nestler and Dr. Mike Browning for their input during the planning and implementation of this work. We also thank Dr. Sandra Aamodt for careful reading of this manuscript.

Correspondence should be addressed to Dr. A.J. Scheetz, Yale University, Department of Biology, Kline Biology Tower, New Haven, CT 06520.

Copyright $\odot 1996$ Society for Neuroscience $0270-6474 / 96 / 161460-10 \$ 05.00 / 0$ could be a key molecular component in the refinement process, signaling to postsynaptic cells the degree of correlated activity they receive and dictating which synapses get stabilized. This idea is supported by the observation that antagonism of NMDA receptors disrupts the retinotopic map (Cline and ConstantinePaton, 1989) and causes desegregation of eye-specific stripes (Cline et al., 1987) in tadpoles.

Nothing is known about how NMDA receptor activation can lead to structural synaptic plasticity. Calcium influx through NMDA receptor channels is important for some forms of synaptic plasticity (Kullman et al., 1992; Lynch et al., 1983), which also involve protein phosphorylation (Aoki and Siekevitz, 1985; Malenka et al., 1986; Malinow et al., 1988). Also, several calciumdependent kinases are highly cnriched in ncurons (Nairn ct al., 1985; Schulman, 1991). Thus, one scenario for activity-dependent structural plasticity is that calcium entering through NMDA receptors activates calcium-dependent kinases that phosphorylate a subset of proteins, changing their function and leading to increased stability of coactivated synapses. We have examined this possibility by monitoring the phosphorylation state of tectal proteins after NMDA receptor stimulation. We have detected five proteins that show greatly increased phosphorylation under conditions designed to activate tectal NMDA receptors maximally and relatively selectively.

\section{MATERIALS AND METHODS}

Materials. Radioactive orthophosphate and $\left[\gamma^{32} \mathrm{P}\right]$ ATP were obtained from Dupont NEN (Boston, MA). All other reagents were obtaincd from Sigma (St. Louis, MO), except for trans-1-amino-1,3-cyclopentanedicarboxylic acid (trans-ACPD) and 2-amino-5-phosphopentanoic acid (AP-5), which were obtained from Research Biochemicals International (Natick, MA), and phorbol esters, which were obtained from LC Labs (Woburn, MA).

NMDA-stimulated protein phosphorylation. Normal tadpoles, T\&K stage XV-XVIII (Taylor and Kollros, 1946), were anesthetized with $0.1 \%$ 3-aminobenzoic acid ethyl ester, methanesulfonate salt. The skin, skull, 
and dura were folded back, and both tectal lobes were removed from the brain. The excised tecta were then placed in a $1.6 \mathrm{ml}$ centrifuge tube containing $0.5 \mathrm{ml}$ of preoxygenated bicarbonate buffer, $\mathrm{pH} 7.3$ (112 mM $\mathrm{NaCl}, 2 \mathrm{mM} \mathrm{KCl}, 17 \mathrm{~mm} \mathrm{NaICO} \mathrm{ICO}_{3}, 3 \mathrm{mM} \mathrm{CaCl}, 150 \mu \mathrm{M} \mathrm{MgCl}_{2}, 2.2 \mathrm{~mm}$ glucose, and a trace of phenol red to indicate $\mathrm{pH}$ ). The tubes were weighed both before and after addition of the tecta and then placed for $30 \mathrm{~min}$ in a heated block prewarmed to $37^{\circ} \mathrm{C}$. After this equilibration, $1-3$ $\mathrm{mCi}(3-7 \mu \mathrm{l})$ of $\left[{ }^{32} \mathrm{P}\right.$ ]orthophosphoric acid was added to the tube, and loading of the tissue was allowed to progress for an additional $1.5 \mathrm{hr}$. The solution was then removed, and freshly oxygenated buffer containing 10 $\mu \mathrm{M}$ glutamate and either $60 \mu \mathrm{M}$ AP-5 or $50 \mu \mathrm{M}$ NMDA was added. After a brief drug exposure, usually $30 \mathrm{sec}$, the solution was removed rapidly, and the tecta were homogenized in $15 \mu \mathrm{l}$ of stop buffer $[9.5 \mathrm{M}$ urea, $0.5 \%$ SDS, and 4.2\% 2-mercaptoethanol $(\mathrm{v} / \mathrm{v})] / \mathrm{mg}$ tectal tissue. Homogenates were allowed to incubate at room temperature for $1 \mathrm{hr}$ before an equal volume of swamp buffer ( $9.5 \mathrm{M}$ urea, $5 \%$ NP-40, $4.2 \%$ 2-mercaptoethanol, and $4 \%$ ampholines, $\mathrm{pH} 3.5-10.0$ ) was added. Samples were sheared by passing through a 22 gauge needle three times, and triplicate $3 \mu$ l aliquots were spotted onto Whatman P-81 filter disks. The disks were incubated in $10 \%$ trichloroacetic acid (TCA) at $4^{\circ} \mathrm{C}$ for $30 \mathrm{~min}$, followed by several rinses with $10 \%$ TCA at room temperature. Disks were dried, and radioactive incorporation into protein was measured by liquid scintillation. Equal amounts of TCA-precipitatable radioactivity were loaded onto a Multiphor II two-dimensional electrophoresis unit according to the specifications of the manufacturer. The isoelectric separation range (IEF) was between 4 and 7 , and the second dimension was an 8-18\% exponential SDS-PAGE, unless noted otherwise. Gel dimensions were always $11 \mathrm{~cm}(\mathrm{IEF}) \times 19 \mathrm{~cm}($ SDS-PAGE). Gels were fixed, dried, and autoradiograplied with intensifying screens for $1 \mathrm{~d}$ to 3 weeks, depending on the amount of radioactivity that was loaded. Optimal cquilibration and stimulation conditions were established in preliminary experiments (see below). Tissue viability was monitored in pilot studies by extracellular recordings that demonstrated ongoing spontaneous action potential activity under the incubation conditions used (Constantine-Paton and Hickmott, unpublished data). One-dimensional gels were also used to monitor protein degradation and phosphate incorporation. NMDA receptor antagonist and agonist concentrations were chosen on the basis of previous experiments that examined both spontaneous and evoked activity in the tectum (Debski and Constantine-Paton, 1988; Udin et al., 1992). Ten micromolar glutamate in combination with $50 \mu \mathrm{M}$ NMDA was chosen because this was the highest concentration of these two agonists that produced phosphorylation that could be inhibited by concentrations of AP-5 known to specifically inhibit NMDA receptors. Higher concentrations of either NMDA alone or glutamate alone resulted in increased phosphorylation that could not be inhibited by AP-5 (data not shown).

The amount of ${ }^{32} \mathrm{P}$ incorporation into individual spots was determined by densitometry. For the measurement of NMDA-stimulated phosphorylation, each observation represents the difference between two gels, one stimulated with $60 \mu \mathrm{M}$ AP-5 and $10 \mu \mathrm{M}$ glutamate and one stimulated with $50 \mu \mathrm{M}$ NMDA and $10 \mu \mathrm{M}$ glutamate. Each gel pair was processed in parallel and exposed on the same film in the same cassette.

To examine proteins phosphorylated by activation of protein kinase $\mathrm{C}$ $(\mathrm{PKC})$ in whole tecta, $100 \mathrm{nM}$ of either phorbol 12-myristate 13-acetate (PMA) or the inactive isomer $4 \alpha$-phorbol 12 -myristate 13 -acetate $(4 \alpha-$ PMA) was applied for $10 \mathrm{~min}$ to tecta prepared as for NMDA-stimulated phosphorylation. Proteins were separated by two-dimensional electrophoresis and autoradiographed.

Subcellular fractionation. Synaptosomes were prepared by the method of Breer and Jeserich (1980). Briefly, whole tadpole brains were weighed and homogenized with 12 passes of a Teflon homogenizer in 10 volumes of ice-cold $0.1 \mathrm{M}$ Tris containing $0.25 \mathrm{M}$ sucrose, $\mathrm{pH} 7.3$. All steps were performed at $4^{\circ} \mathrm{C}$. Samples were centrifuged for 15 min at $1200 \times \mathrm{g}$. The supernatant (S1) was removed and placed on ice. The pellet was resuspended in the same volume of homogenization solution and centrifuged again. The supernatant (S2) was removed, and the pellet was resuspended and centrifuged again. The supernatant (S3) was combined with S2 and centrifuged for $30 \mathrm{~min}$ at $15,000 \times \mathrm{g}$. The resulting pellet was resuspended with $\mathrm{S} 1$ and mixed $1: 5(\mathrm{v} / \mathrm{v})$ with $12 \%$ Ficoll in $0.25 \mathrm{M}$ sucrose, $\mathrm{pH}$ 7.3. The slurry was centrifuged for $40 \mathrm{~min}$ at $10,000 \times g$, and the synaptosomes were removed from the surface under visual guidance. Synaptosomes were either used immediately or quick-frozen for future use. There was no difference in properties between frozen and fresh synaptosomes. Synaptosome purity was assessed by synapsin 1 phosphorylation (Krueger et al., 1977) and electron microscopy (data not shown).

Nuclear extracts were prepared by the method of Lee et al. (1988), with modifications. Briefly, whole tadpole brains were homogenized in 0.15 volumes of buffer A [10 mM HEPES-KOH, pH 7.8, $10 \mathrm{mM} \mathrm{KCl,} 1.5 \mathrm{~mm}$ $\mathrm{MgCl}_{2}$, and $0.5 \mathrm{~mm}$ dithiothreitol(DTT)]. The homogenate was centrifuged for $20 \mathrm{~min}$ at $13,600 \times \mathrm{g}$. The resulting pellet was resuspended in 0.1 volumes of buffer $\mathrm{C}(20 \mathrm{~mm}$ HEPES-KOH, $\mathrm{pH} 7.8,429 \mathrm{mM} \mathrm{NaCl}, 1.5$ $\mathrm{mM} \mathrm{MgCl}_{2}, 25 \%$ glyccrol, $0.2 \mathrm{mM}$ EDTA, and $0.5 \mathrm{mM}$ DTT) and incubated on ice for $30 \mathrm{~min}$ with stirring. Samples were cleared by centrifugation for $5 \mathrm{~min}$ at $13,600 \times \mathrm{g}$. The supernatant was dialyzed against buffer D (20 mM HEPES-KOH, pH 7.8, $20 \mathrm{mM} \mathrm{KCl,} 2 \mathrm{mM} \mathrm{MgCl}, 20 \%$ glycerol, $0.2 \mathrm{~mm}$ EDTA, and $0.5 \mathrm{~mm}$ DTT) overnight at $4^{\circ} \mathrm{C}$. Extracts were quick-frozen until use.

In vitro phosphorylation. Whole tadpole brains were homogenized in 0.15 volumes of phosphate buffer $\left(10 \mathrm{mM} \mathrm{NaPO}_{4}, \mathrm{pH} 7.4,5 \mathrm{mM}\right.$ EDTA, $5 \mathrm{~mm}$ EGTA, $1 \mathrm{~mm} \mathrm{Na} \mathrm{VO}_{4}, 10 \mathrm{mM} \mathrm{Na}_{4} \mathrm{P}_{2} \mathrm{O}_{7}, 10 \mathrm{H}_{2} \mathrm{O}, 50 \mathrm{~mm} \mathrm{NaF}$, and $10 \mu \mathrm{g} / \mathrm{m}$ l each of leupeptin, antipain, chymostatin, and pepstatin, and 0.1 $\mathrm{M}$ phenylmethylsulfonyl fluoride and $10 \mathrm{u} / \mathrm{ml}$ aprotinin) and quick-frozen until use. In vitro phosphorylation was performed according to Guitart and Nestler (1989) by adding $1.0-10 \mu \mathrm{g}$ of protein to a reaction mixture containing $62.5 \mathrm{~mm}$ Tris, $\mathrm{pH} 7.4,10 \mathrm{mM} \mathrm{MgCl}_{2}, 0.05 \%$ NP-40, $10 \mathrm{mM}$ DTT, $1 \mathrm{mM}$ EDTA, $1 \mathrm{mM}$ EGTA, and $15 \mu \mathrm{M}\left[\gamma_{-}{ }^{32} \mathrm{P}\right] \mathrm{ATP}(3.5 \mu \mathrm{Ci} /$ reaction). For $\mathrm{PKC}$-dependent phosphorylation, $2 \mathrm{mM} \mathrm{CaCl}, 125 \mathrm{nM}$ phorbol 12,13-dibutyrate, and $1 \mu \mathrm{M}$ KN-62 were included in the reaction mixture. For $\mathrm{Ca}^{2+}$ calmodulin (CaM) kinase II-dependent phosphorylation, $2 \mathrm{~mm} \mathrm{CaCl}_{2}, 20 \mu \mathrm{g} / \mathrm{ml}$ calmodulin, and $2 \mu \mathrm{M} \mathrm{PKC}_{19-31}$ were included in the reaction mixture. For cAMP-dependent phosphorylation, $12.5 \mu \mathrm{M}$ 8-bromo-cyclic AMP was included in the reaction mixture. The final volume of the reaction was $50 \mu \mathrm{l}$. After $5 \mathrm{~min}$, the reaction was stopped by adding an equal volume of stop solution consisting of $3 \%$ NP-40, $5 \%$ 2 -mercaptoethanol, and $2 \%$ ampholines, $\mathrm{pH} 3.5-10.0$. This mixture was then added to $0.09 \mathrm{gm}$ of urea. The samples were allowed to solubilize for $1 \mathrm{hr}$ at room temperature before being separated by two-dimensional electrophoresis. Nuclear extracts were phosphorylated using the same conditions as above.

Synaptosomes were phosphorylated under nonlysing conditions. Seven to ten micrograms of synaptosome protein were incubated at $37^{\circ} \mathrm{C}$ in bicarbonate buffer (see above) with $15 \mu \mathrm{M}\left[\gamma^{32} \mathrm{P}\right] \mathrm{ATP}(3.5 \mu \mathrm{Ci} /$ reaction) for $30 \mathrm{~min}$. Samples were solubilized as above.

Labeling tectal ATP pools. To determine the optimal labeling time, tecta were excised and incubated in $\left[{ }^{32} \mathbf{P}\right]$ orthophosphate for various amounts of time and then homogenized in phosphate buffer (see above). Equal amounts of protein $(10 \mu \mathrm{l})$ were added to $40 \mu$ l of reaction containing exogenous histone $F_{2} \mathrm{~b}(0.5 \mu \mathrm{g} / \mu \mathrm{l})$ and 8 -bromo-cyclic AMP $(12.5 \mu \mathrm{M})$. Samples were incubated for $1 \mathrm{~min}$ at $37^{\circ} \mathrm{C}$. The reaction was stopped by the addition of $50 \mu$ l of a solution containing $10 \mathrm{~mm}$ ATP and $250 \mu \mathrm{M}$ EDTA. Samples were spotted onto P-81 phosphoccllulose paper (Whatman) and rinsed under running water overnight. The paper was then rinsed in absolute ethanol and ether before being dricd. Radioactivity was measured by liquid scintillation. To assess the biochemical viability of the tissue, whole excised tecta were incubated in the absence of orthophosphate for various times and homogenized in phosphate buffer. Exogenous histone, 8-bromo-cyclic AMP, and $10 \mu \mathrm{M}\left[\gamma_{-}{ }^{32} \mathrm{P}\right] \mathrm{ATP}$ $(30 \mathrm{Ci} / \mathrm{mmol})$ were added to samples containing equal protein. The reaction was stopped, and the samples were spotted onto P-81 filter paper and processed as above.

Comparison of in vivo and in vitro labeled proteins. Comparison of in vivo and in vitro labeled proteins was accomplished with either mixing assays or two-dimensional phosphopeptide mapping. For mixing experiments, half of each of the two samples to be compared was mixed together and loaded onto one gel, and the remaining unmixed samples were loaded onto separate gels. When these mixing experiments were performed, gels separating between $\mathrm{pH} 5.5$ and 6.5 were used to allow very high resolution of proteins focusing in the range of interest. In other experiments, phosphopeptide mapping was used to compare proteins phosphorylated in the various in vitro phosphorylation assays. The method was slightly modified from Mitsui et al. (1993), with the first dimension electrophoresis performed using the Multiphor system and electrophoresis buffer embedded in $2 \%$ agarose. Briefly, gel pieces containing either labeled NARPP-21 or -50 were washed, dried and trypsinized. Samples were freeze-dried and resuspended in $10 \%$ acetic acid, $1 \%$ pyridine $(\mathrm{pH} 3.5)$. Phosphopeptides were separated on the first dimension by electrophoresis on thin-layer cellulose sheets for $90 \mathrm{~min}$ at $400 \mathrm{~V}$, followed by chromatography in the second dimension in a solution containing pyridine/1-butanol/water/acetic acid $(10: 15: 12: 3, \mathrm{v} / \mathrm{v})$. Sheets were dried and exposed to x-ray film or Fuji BAS 2000 imaging plates. 


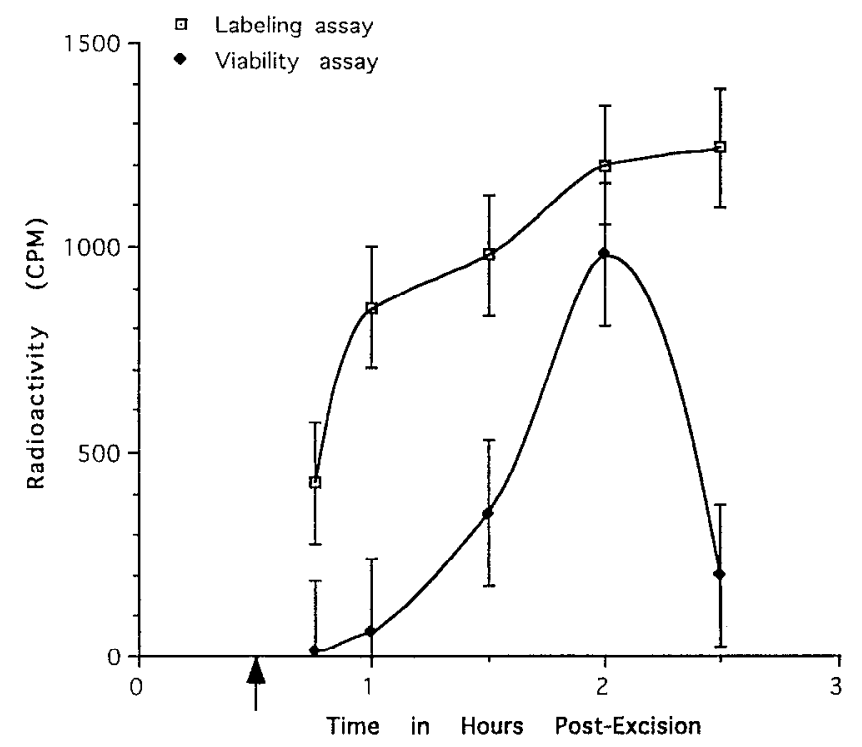

Figure 1. Time courses of endogenous ATP labeling and tissue viability assessed by cAMP-dependent kindse activily in excised tecla. To evaluate labeling, excised tecta were incubated with $\left[{ }^{32} \mathrm{P}\right]$ orthophosphate for the indicated times and then homogenized. The homogenate was used as a source for both cAMP-dependent kinase and $\mathrm{A}^{\prime} \mathrm{TP}$ in the labeling assay. The amount of ${ }^{32} \mathrm{P}$ incorporated into exogenously added histone is represented by the open boxes $(n=5)$. The arrow indicates the time that $\left[{ }^{32} \mathrm{P}\right]$ orthophosphate was added in the labeling assay. In a separate series of experiments to determine tissue viability in vitro, excised tecta were incubated under similar conditions except that no [ ${ }^{32}$ P]orthophosphate was added. The tissue was homogenized and tested by the viability assay, in which exogenous $\left[\gamma^{32} \mathrm{P}\right] \mathrm{ATP}$ was added and the amount of radioactivity incorporated into exogenously added histone was measured (closed diamonds; $n=5$ ). The results show that although radioactivity is still being incorporated into ATP at $2.5 \mathrm{hr}$ postexcision $\left(2 \mathrm{hr}\right.$ of $\left[{ }^{32} \mathrm{P}\right]$ orthophosphate exposure), cAMP-dependent kinase activity is severely reduced, indicating deterioration of the tissue.

\section{RESULTS}

\section{Conditions for receptor-stimulated tectal phosphorylation}

\section{Optimal phosphorylation conditions}

Conditions for the front phosphorylation assays were established using two measures: the time needed to maximally load intracellular ATP pools with ${ }^{32} \mathrm{P}$ and the maximum amount of time that tecta remained viable in vitro. First, an endogenous cAMPdependent kinase assay was used to monitor incorporation of ${ }^{32} \mathbf{P}$ into endogenous ATP, a procedure referred to here as the labeling assay. Second, because this kinase is involved in many aspects of cellular function (Krebs and Beavo, 1979), we used its activity as a measure of tissue viability by using exogenous $\left[\gamma^{32}\right.$ P]ATP as a source of phosphate for a similar endogenous kinase assay, referred to here as the viability assay.

For the labeling assay, tecta were incubated for various times with $\left[{ }^{32} \mathrm{P}\right]$ orthophosphate to label tectal ATP pools, the tissue was homogenized, and endogenous cAMP-dependent kinase activity was then measured without exogenous $\left[\gamma_{-}{ }^{32} \mathrm{P}\right] \mathrm{ATP}$. The radioactivity incorporated under these conditions into exogenously applied histone $\mathrm{f}_{2} \mathrm{~b}$, a substrate for the cAMP-dependent kinase (Kuo and Greengard, 1970), should be related to endogenous $\left[\gamma^{32}\right.$ P]ATP levels (Fig. 1). To exclude potential effects on kinase activity caused by the removal of the tecta, orthophosphate was added at 30 min postexcision, and the first determination (at 45 min) actually represents $15 \mathrm{~min}$ of loading. There was an initial increase in $\left[\gamma^{-32} \mathrm{P}\right] \mathrm{ATP}$ levels during the first hour of loading, followed by a plateau that was established at $\sim 1.5 \mathrm{hr}$.

For viability assays, the source of radioactive phosphate was exogenous $\left[\gamma-{ }^{32} \mathrm{P}\right]$ ATP rather than orthophosphate. Homogenized tectal tissue was again the source of cAMP-dependent kinase. After incubation without orthophosphate for varying times, tissue was homogenized, $\left[\gamma^{32}\right.$ P $]$ ATP was added, and cAMP-dependent kinase activity was assayed as before. Figure 1 shows that kinase activity increased throughout the postexcision period until it peaked at $2 \mathrm{hr}$. The rapid decline in activity after 2 hr most likely indicates that the viability of the preparation has deteriorated. The basis for the steady increase in cAMPdependent kinase activity is unclear. In light of these observations, we decided to do all experiments at $2 \mathrm{hr}$ postexcision, which allowed for $1.5 \mathrm{hr}$ of radioactive labeling in the front phosphorylation assay.

\section{Optimal stimulus and stimulus duration}

Initial experiments showed that phosphorylation of many proteins was dependent on the concentration and duration of glutamate stimulation and $\mathrm{Mg}^{2+}$ concentration (data not shown). At high glutamate concentrations, however, we were unable to inhibit this phosphorylation with AP-5, which suggests that strong stimulation with glutamate does not reveal NMDA receptor-specific phosphorylation. We did find that stimulation with low concentrations of glutamate, $10 \mu \mathrm{M}$, in the presence of $50 \mu \mathrm{M}$ NMD $\Lambda$ (Glut + NMDA application) resulted in phosphorylation that could be inhibited specifically when $60 \mu \mathrm{M}$ AP-5 was present 15 min before and during the Glut + NMDA application ( $n=4$ gels) (see below). To examine the effect of Glut + NMDA application on overall phosphorylation, we loaded tissue for the optimal labeling time and then stimulated tecta for various times from 0 to 2 min and assayed total radioactive protein (Fig. 2). There was an initial decrease in radioactive protein, which could reflect an increase in phosphatase activity. This decrease in radioactive protein was then followed by an increase and a plateau lasting between $30 \mathrm{sec}$ and $1 \mathrm{~min}$ from the onset of stimulation. This plateau was then followed by another increase in radioactive protein, which may reflect a use-dependent stimulation of radioactive ${ }^{32} \mathrm{P}$ incorporation into ATP and thus increased availability of $\left[\gamma^{32} \mathrm{P}\right]$ ATP. On the basis of these observations, we concluded that $30 \mathrm{sec}$ was the optimal stimulus duration.

\section{Detection of NMDA reception activation-responsive phosphoproteins (NARPPs)}

Stimulation of tecta by Glut + NMDA application resulted in the phosphorylation of five proteins (Fig. $3 A$ ) with isoelectric points between 4 and 7 . Figure $3 B$ shows that phosphorylation of these proteins could be inhibited by blocking NMDA receptors with a 15 min incubation in $60 \mu \mathrm{M} \mathrm{AP-5}$ before and during Glut + NMDA application. Application of either $10 \mu \mathrm{M}$ glutamate alone (Fig. $3 D$ ) or $50 \mu \mathrm{M}$ NMDA alone (Fig. $3 E$ ) did not produce phosphorylation of these proteins. This spot pattern and intensity was designated basal phosphorylation and was comparable with phosphorylation seen in unstimulated tecta (Fig. $3 F$ ). Stimulation with $10 \mu \mathrm{M}$ glutamate plus $60 \mu \mathrm{M}$ AP-5, although slightly increasing the phosphorylation of these proteins over the levels seen with $10 \mu \mathrm{M}$ glutamate application, produced a more consistent spot pattern than did $10 \mu \mathrm{m}$ glutamate alone (Fig. 3C). Therefore, to eliminate any possible variable effect of the low concentration of glutamate used, all measurements were made using $10 \mu \mathrm{M}$ glutamate plus $60 \mu \mathrm{M}$ AP-5 (Glut + AP-5) application as control. We termed the five proteins phosphorylated by 


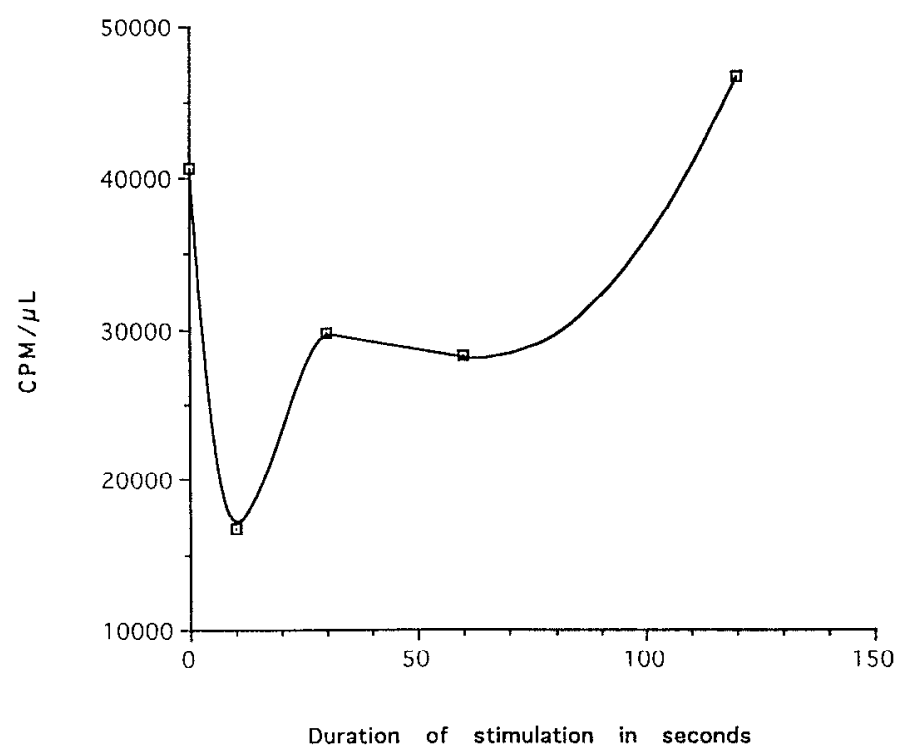

Figure 2. Time course of NMDA receptor-stimulated ${ }^{32} \mathrm{P}$ incorporation into protein. Tecta were excised and incubated for $1.5 \mathrm{hr}$ in the presence of $\left[{ }^{32} \mathrm{P}\right]$ orthophosphate after a $30 \mathrm{~min}$ preincubation. The incubation medium was then aspirated, and fresh buffer containing $10 \mu \mathrm{M}$ glutamate and $50 \mu \mathrm{M}$ NMDA was added. The tissue was stimulated for the indicated times and then homogenized as for two-dimensional gel analysis. The amount of TCA-precipitatable ${ }^{32} \mathrm{P}$ was then measured by liquid scintillation counting. These results are representative of three independent determinations. Open boxes with dot in center indicate $\mathrm{cpm} / \mathrm{mic}$ iliter sample.

Glut + NMDA application NARPPs. Four NARPPs focused reliably in 29 separate two-dimensional gels from tecta stimulated with Glut + NMDA. NARPP-90, however, had an isoelectric point at the extreme acid end of the gels and consequently did not focus reliably. We did not examine this protein further for this reason. Because we loaded equal amounts of TCA-precipitatable radioactivity, it was important to determine whether the amount of protein that was loaded varied as a function of treatment. In some experiments, gels were silver-stained after autoradiography, and arbitrary spots were scanned. In general, there was no systematic effect of stimulation condition on the amount of protein present, and this amount did not differ by $>10 \%$ between Glut + NMDA application and Glut + AP5 application (data not shown).

Measurement of radioactive phosphate incorporation into NARPPs demonstrated a robust increase in phosphorylation with Glut + NMDA application compared with Glut + AP-5 application (Table 1). NARPP-45 and -21 incorporated approximately four times more radioactive phosphate with Glut + NMDA application compared with Glut + AP-5 application, whereas Glut + NMDA application caused at least a 10-fold incorporation increase over Glut + AP-5 application for NARPP-50 and -10 . This effect was $\mathrm{Mg}^{2+}$-dependent because if $\mathrm{Mg}^{2+}$ concentrations were elevated 10-fold, NARPP phosphorylation was reduced to background (data not shown) ( $n=3$ gels).

\section{Subcellular distribution and in vitro phosphorylation of NARPPs}

In vitro phosphorylation of tectal proteins revealed that proteins comigrating with NARPP-21 and -50 were substrates for endogenous PKC (Fig. 4A). The identity of these proteins as NARPP-21 and -50 was verified by mixing samples from front-phosphorylated tecta with NARPPs phosphorylated in tectal homogenates by
PKC (Fig. 5A) and comparing the spots with spots from nonmixed samples (Fig. $5 B$ ). No NARPP seemed to be an in vitro substrate for the endogenous calcium and CaM-dependent kinase II (Fig. $4 B$ ) or cAMP-dependent kinase (data not shown). Attempts at subcellular fractionation after NARPP phosphorylation in excised tecta were unsuccessful even in the presence of various phosphatase inhibitors. This was probably attributable to the transient nature of NARPP phosphorylation, possibly caused by a high level of phosphatase activity induced by NMDA receptor stimulation.

We were able to use the ability to phosphorylate NARPP-21 and -50 by $\mathrm{PKC}$ in vitro to study the subcellular location of these two proteins. To identify proteins located in the postsynaptic density, we made synaptosomes from whole tadpole brains and exposed them to exogenous $\left[\gamma_{-}{ }^{32} \mathrm{P}\right] \mathrm{ATP}$ in the presence of physiological buffer. By using this approach, we identified a protein comigrating with NARPP-50 (Fig. 4C). A protein comigrating with NARPP-21 was found in the nuclear fraction (Fig. 4D). The identity of the proteins phosphorylated in subcellular fractions was confirmed by comparing the two-dimensional phosphopeptide maps generated from NARPP-21 (Fig. 5C) and -50 (Fig. 5E) phosphorylated in whole tectal homogenates with the twodimensional maps from the 21 (Fig. 5D) and $50 \mathrm{kDa}$ (Fig. $5 F$ ) proteins phosphorylated in nuclear extracts and synaptosomes, respectively.

Confirmation that both NARPP-21 and -50 were PKC substrates in whole tecta was obtained from experiments in which tecta were stimulated with PMA (100 nM) for 10 min. Many proteins, including NARPP-21 and -50 , were phosphorylated by this treatment (Fig. $6 A)(n=3)$. Treatment with the $4 \alpha$ isomer, which is inactive in in vitro assays, resulted in appreciable but lower NARPP-21 phosphorylation than with PMA (Fig. $6 B)(n=3)$.

\section{Time course of NARPP phosphorylation}

To examine the time course of NARPP phosphorylation, tecta were labeled and Glut + NMDA was applied for times ranging from 10 to $60 \mathrm{sec}$. The radioactivity incorporated into the spots corresponding to NARPP-21, -45 , and -50 was measured and plotted against time (Fig. 7). The baseline phosphorylation of NARPPS was actually slightly higher than that observed shortly after the onset of stimulation. This decrease was followed by an increase in phosphate incorporation that reached a maximum at $30 \mathrm{sec}$ and then decreased to levels below baseline at $1 \mathrm{~min}$. No other proteins became phosphorylated in an NMDA receptorspecific fashion at earlier or later stimulus durations.

A methodological consideration for these experiments is whether changes in the specific activity of the $\left[\gamma^{32} \mathrm{P}\right] \mathrm{ATP}$ in the tissue are being induced by stimulation and whether these changes alone could account for the changes in phosphoproteins that we have detected (Garrison, 1993). We did not determine $\left[\gamma^{32}\right.$ P]ATP specific activity directly. Several lines of evidence, however, suggest that changes in the specific activity of $\left[\gamma_{-}{ }^{32} \mathrm{P}\right]$ ATP cannot account for the phosphorylation of NARPPs that we have observed. First, all stimulations that compared Glut + NMDA application versus Glut + AP-5 application were performed at $30 \mathrm{sec}$ of stimulation, a time when steady-state labeling conditions were achieved (Fig. 2). Second, although we always loaded equal amounts of radioactive protein rather than equal amounts of total protein onto our gels, samples had to be adjusted by $<10 \%$ in volume, and subsequent silver-staining of 

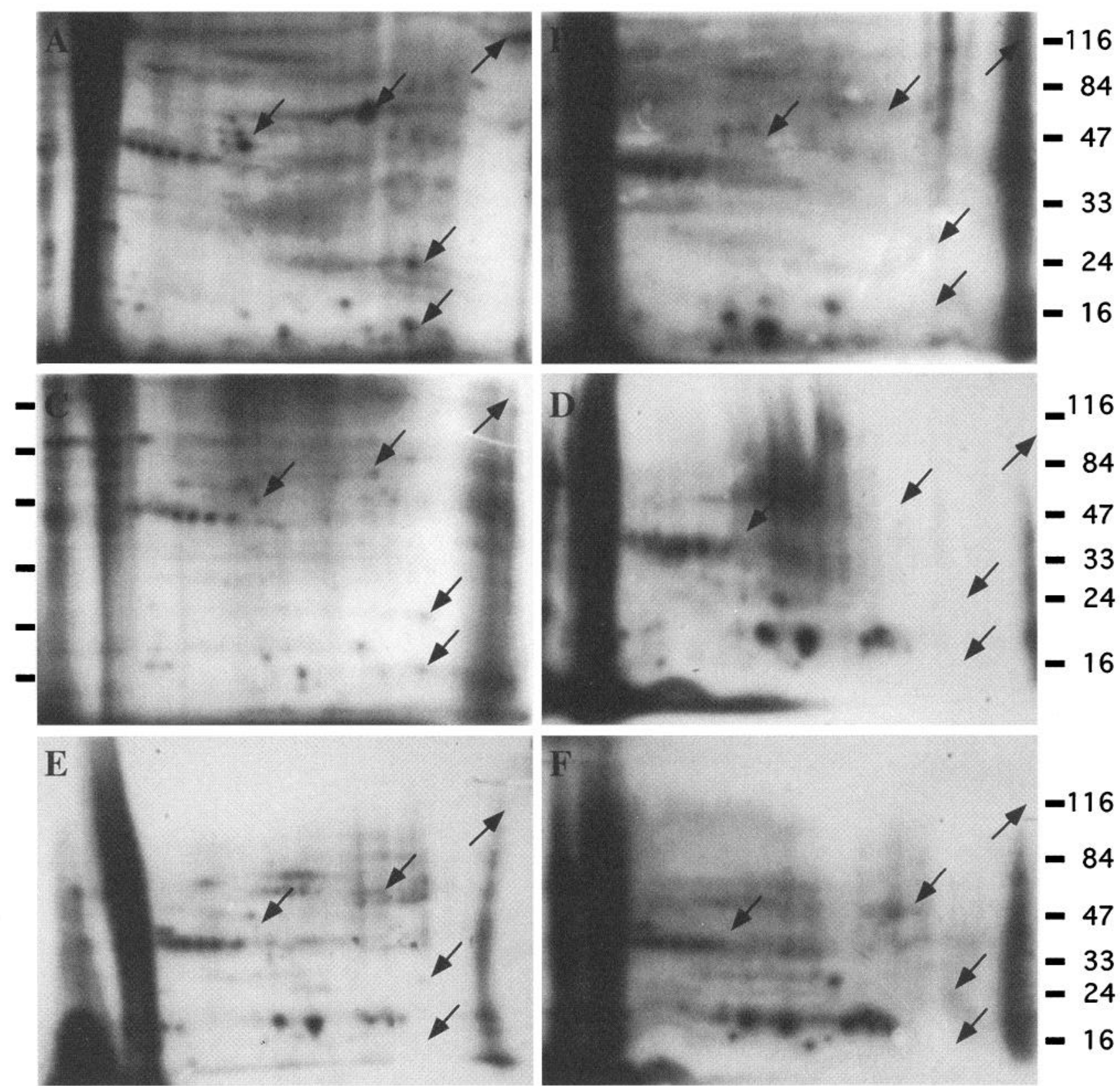

4

IEF

74

IEF

7

Figure 3. NMDA receptor stimulation leads to the phosphorylation of five proteins in the $\mathrm{pH} 4-7$ range. Whole excised tecta were incubated for 30 min in prelabeling solution followed by $1.5 \mathrm{hr}$ of incubation in labeling solution containing $1-2 \mathrm{mCi}$ of carrier-free [ $\left.{ }^{32} \mathrm{P}\right]$ orthophosphate. Tecta were then stimulated for $30 \mathrm{sec}$ with either $10 \mu \mathrm{M}$ glutamate plus $50 \mu \mathrm{M}$ NMDA $(A)$ or $10 \mu \mathrm{M}$ glutamate plus $60 \mu \mathrm{M}$ AP-5 $(C)$. Gels $A$ and $C$ were run simultaneously and are one pair of the four pairs quantified in Table 1 . They are qualitatively representative of 25 other gel pairs from 8 independent experiments. Arrows indicate the phosphoproteins that are responsive to Glut + NMDA application. The other gels in this figure show qualitative differences. $B$, A representative autoradiograph from tissue treated with $60 \mu \mathrm{M}$ AP-5 for 15 min before Glut + NMDA application $(n=4)$. $D$, A representative autoradiograph from tissue treated with $10 \mu \mathrm{m}$ glutamate alone $(n=4)$. Arrows point to where NARPPs should be seen. $E$, A representative autoradiograph from tissue treated with $50 \mu \mathrm{M}$ NMDA alone $(n=3)$. $F$, A representative autoradiograph from untreated tissue $(n=7)$. The second dimension for gels $A, B$, and $C$ in this figure was $8 \%$ acrylamide.

gels indicated that total protein loaded varied by $<10 \%$. This variability was independent of the stimulation condition. Finally, $100 \mu \mathrm{M}$ glutamate, which resulted in massive phosphorylation, required $5 \mathrm{~min}$ of stimulation to run down $\left[\gamma^{-32} \mathrm{P}\right]$ ATP noticeably (data not shown). This suggests that at the levels of phosphorylation examined with Glut + NMDA application, ample radioactive ATP was available for activated kinases.

\section{Other regulation of NARPP phosphorylation}

To identify the role that calcium plays in regulating NARPP phosphorylation, dantrolene was used to inhibit the release of intracellular calcium stores (Kojima et al., 1984; Belhage et al., 1992) during Glut + NMDA application. The addition of $30 \mu \mathrm{M}$ dantrolene to the stimulation medium eliminated NARPP phos- 
Table 1. Quantitation of response of NARPPs to NMDA receptor stimulation

\begin{tabular}{|c|c|c|c|c|c|}
\hline & $\begin{array}{l}\text { Molecular weight } \\
(\mathrm{kDa})\end{array}$ & $\begin{array}{l}\text { Isoelectric } \\
\text { point }\end{array}$ & $\begin{array}{l}\text { NMDA + Glut } \\
\text { O.D. + SD }\end{array}$ & $\begin{array}{l}\text { AP-5 + Glut } \\
\text { O.D. + SD }\end{array}$ & $\begin{array}{l}\text { NMDA/AP-5 } \\
\text { ratio (range) }\end{array}$ \\
\hline NARPP-50 & 50 & 6.0 & $350.7 \pm 41.0$ & $34.6 \pm 25.4$ & $10.1(14.6-7.1)$ \\
\hline NARPP-45 & 45 & 5.3 & $189.5 \pm 30.1$ & $43.7 \pm 19.1$ & $4.3(5.6-2.3)$ \\
\hline NARPP-21 & 21 & 6.2 & $26.6 \pm 4.2$ & $5.8 \pm 4.8$ & $4.5(4.9-2.1)$ \\
\hline NARPP-10 & 10 & 6.2 & $63.7 \pm 4.6$ & $5.7 \pm 5.5$ & $11.0(23.3-5.5)$ \\
\hline
\end{tabular}

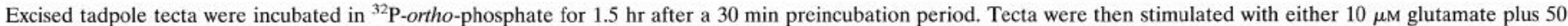

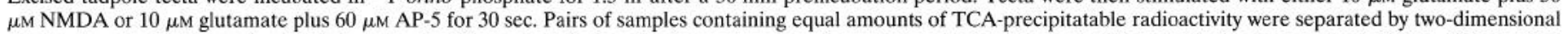

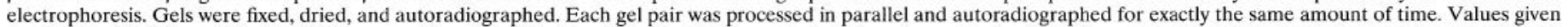

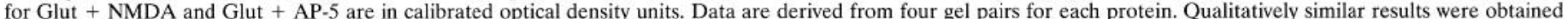

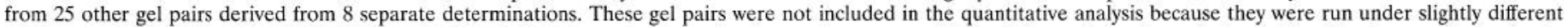

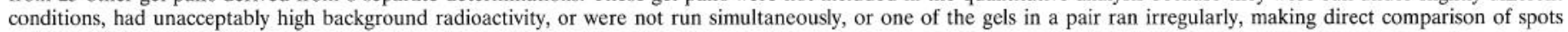
difficult. O.D., Optical density.

phorylation (Fig. 8A). This indicates that NARPP phosphorylation is dependent on calcium derived from intracellular stores.

In addition to the effect of dantrolene on NARPP phosphorylation, we examined the role that activation of other glutamate receptors may play in NARPP phosphorylation. The application of $100 \mu \mathrm{m}$ t-ACPD resulted in NARPP-21 phosphorylation that in some cases exceeded that produced by Glut + NMDA application (Fig. 8B). Thus, NARPP-21 phosphorylation is associated with both NMDA receptor and metabotropic glutamate receptor stimulation.

\section{NARPP phosphorylation and structural synaptic plasticity}

To examine the relationship between NARPP phosphorylation and the structural rearrangement of synapses, experiments were performed using the Glut + NMDA application as above but with tecta obtained from mature frogs. Although there is probably still some ongoing synaptic rearrangement in the tecta of mature animals (Easter et al., 1981), it is markedly reduced compared with the massive shifts in the projection that occur during larval life (Gaze et al., 1974; Reh and Constantine-Paton, 1984). Glut + NMDA application to adult tecta resulted in NARPP-50 and NARPP-21 phosphorylation (Fig. 9A). In contrast to tadpole tecta, in mature tecta $10 \mu \mathrm{M}$ glutamate alone was sufficient to produce significant NARPP-21 phosphorylation (Fig. 9B) $(n=2$ gels).

\section{DISCUSSION}

The key to the postulated involvement of the NMDA receptor in synaptic plasticity is its ability to allow calcium to enter the cell when the $\mathrm{Mg}^{2+}$ block of the channel is removed (Mayer et al., 1984). The events following this calcium flux are poorly understood. This study examined whether activation of NMDA receptors in the developing tadpole tectum results in changes in the phosphorylation state of some proteins. Because there is little data concerning NMDA-stimulated phosphorylation in the tadpole tectum, we selected the front phosphorylation assay, which does not require a priori assumptions about which kinases or which substrates are regulated by NMDA receptor activation. Although application of $50 \mu \mathrm{M}$ NMDA did not have an appreciable effect on protein phosphorylation, coapplication of NMDA and a low concentration of glutamate $(10 \mu \mathrm{M})$ caused robust increases in the phosphorylation of five proteins, which we call NARPPs. The requirement for glutamate and NMDA coapplication is unexpected, but at least two explanations are possible. First, activation of another glutamate receptor subtype could trigger a parallel second messenger pathway synergistic with the
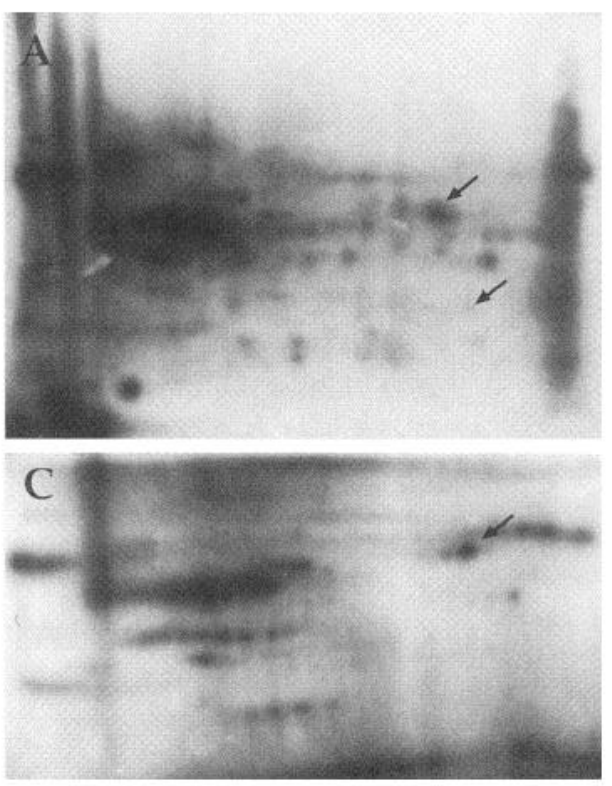

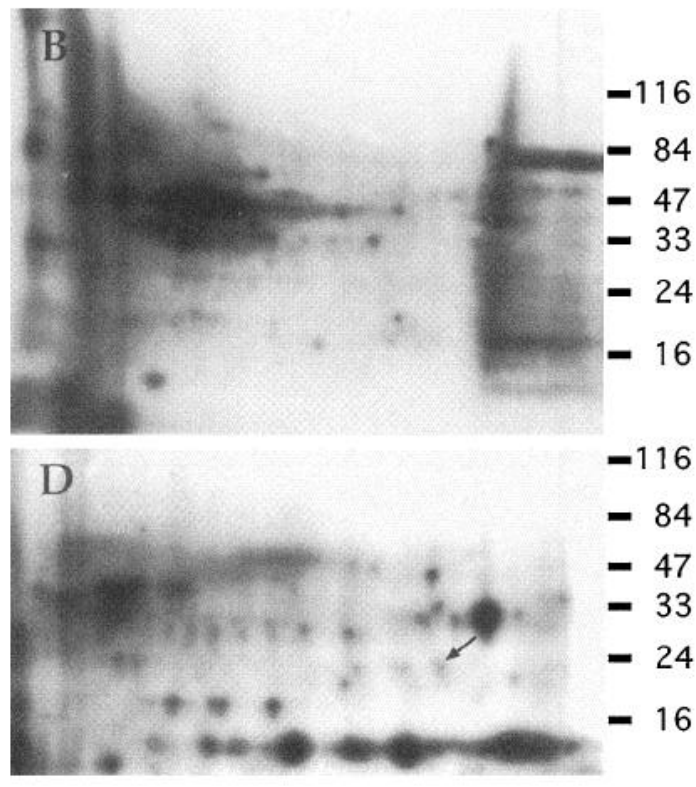

Figure 4. In vitro phosphorylation of whole tectal homogenates and subcellular distribution of NARPPs. Whole tectal homogenates were prepared from excised tecta treated as in Figure 3, except that no radioactivity was added and no drug stimulation was performed. Tecta were then homogenized and subjected to in vitro phosphorylation analysis for PKC $(A)$ and CaM kinase II $(B)$ substrates ( $n=3$ for each). The arrows in $A$ identify NARPP-50 and -21. To determine the subcellular distribution of these two NARPPs, either synaptosomes $(C)$ or nuclear extracts $(D)$ were prepared from whole brains and phosphorylated in vitro. In the case of nuclear extracts $(n=7)$, endogenous PKC was stimulated. The synaptosomal in vitro phosphorylation was performed under nonlysing conditions with exogenously added $\left[{ }^{32} \mathrm{P}-\gamma\right] \mathrm{ATP}(n=4)$. The arrow in $C$ identifies NARPP-50. The arrow in $D$ identifies NARPP- 21 . 
5.5

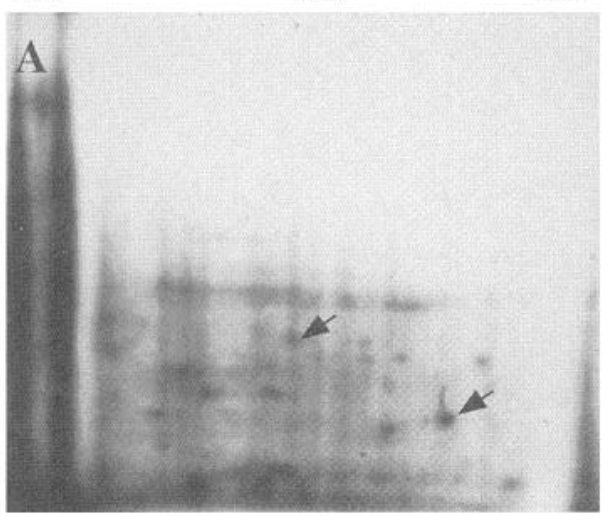

Figure 5. Comparison of in vivo and in vitro phosphorylation of NARPP-21 and -50 . Comparison between spots comigrating in phosphorylation experiments performed in vivo and in vitro were carried out by mixing samples from both assays and comparing the spots with gels from nonmixed samples. The twodimensional gels for this assay were 11 $\mathrm{cm}$ wide and separated proteins with isoelectric points between 5.5 and 6.5. A shows the spot pattern observed when a front-phosphorylated tectal sample was spiked with an equal volume of in vitro phosphorylated, PKC-stimulated tectal protein. $B$ shows a gel of an in vitro phosphorylated sample. Both gels were exposed for the same time. The arrows mark the location of NARPP-50 and -21. Two-dimensional tryptic phosphopeptide mapping of NARPP-21 and -50 was used to compare samples from different in vitro phosphorylation assays. $C$ and $D$ show the phosphopeptide maps generated from NARPP-21 phosphorylated in vitro from whole tecta and nuclear extracts, respectively. $E$ and $F$ show the maps generated from NARPP-50 phosphorylated in vitro from whole tecta and in unlysed synaptosomes, respectively. Numbers identify the various phosphopeptides characteristic of each map. The small $o$ marks the origin.
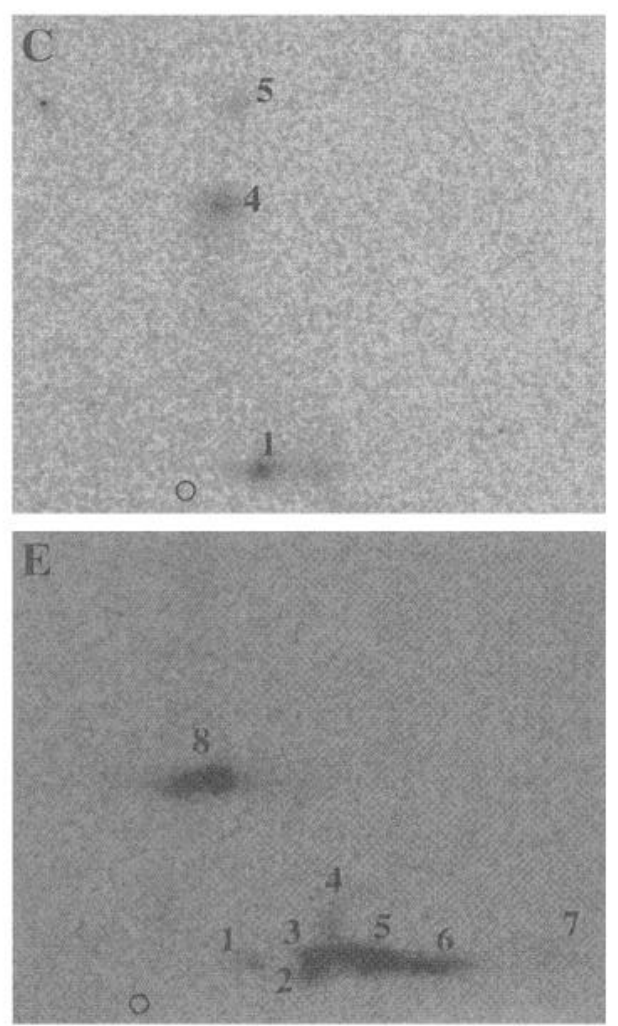
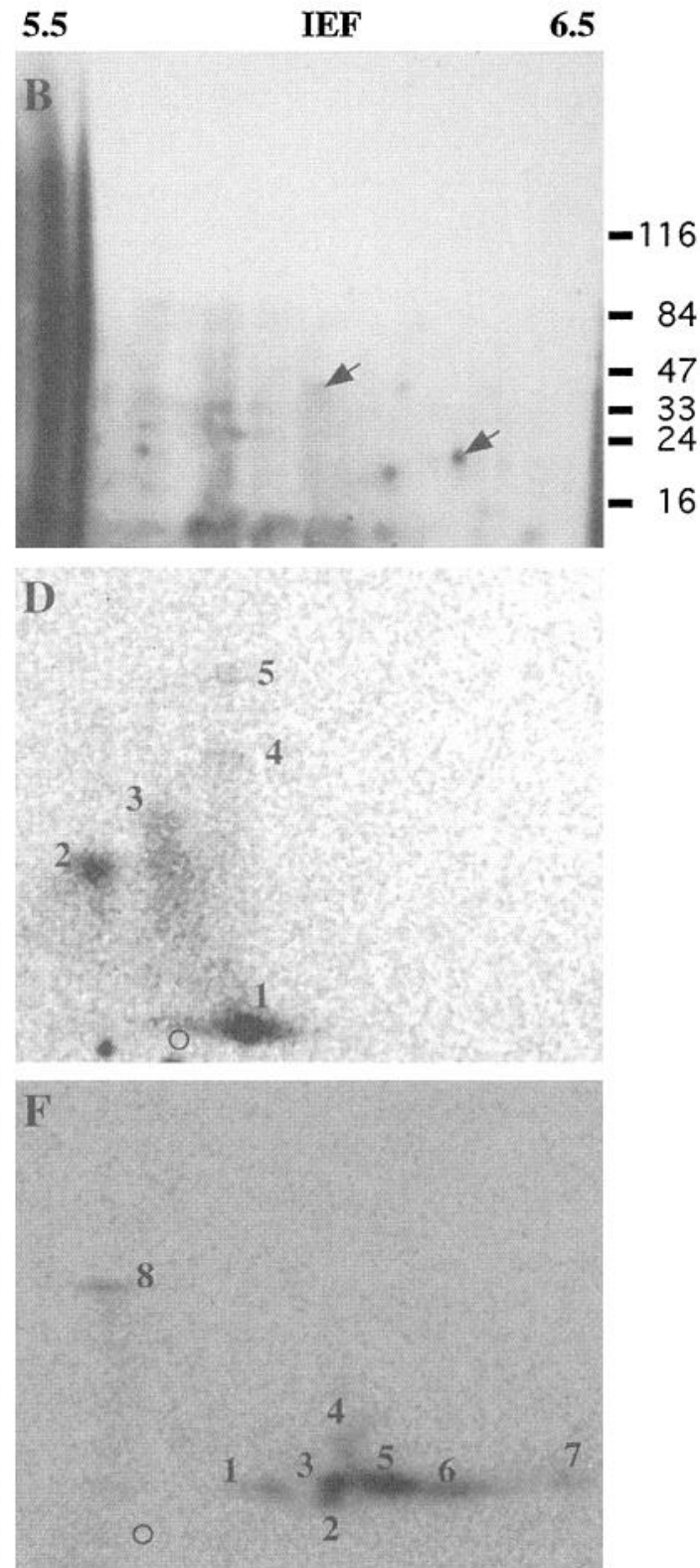

pathway activated by NMDA receptor stimulation. The finding that $\mathrm{t}$-ACPD can increase NARPP-21 phosphorylation implicates the metabotropic glutamate receptors in such a potential synergism. Alternatively or additionally, the depolarization induced by the additional glutamate could lead to a larger calcium influx through NMDA receptors because of their voltage-dependent properties.

The sharp drop in precipitatable radioactive protein during the first $10 \mathrm{sec}$ of stimulation suggests that overall phosphatase activity increases shortly after the onset of Glut + NMDA application. Studies using hippocampal slices demonstrate a similar NMDA application-induced increase in phosphatase activity (Halpain and Greengard, 1990). Our data for individual NARPPs (Fig. 7) also indicate an initial dephosphorylation followed by increased phosphorylation. This suggests that NMDA receptor stimulation rapidly changes the balance between phosphorylation and dephosphorylation.

There have been numerous attempts to associate particular phosphorylation events with synaptic plasticity. Aoki and Siekevitz
(1985) demonstrated a close correlation between cyclic AMPdependent kinase phosphorylation of MAP-2 and the critical period for monocular deprivation in cat visual cortex. Additionally, many investigators have shown that phosphorylation of the PKC substrate GAP-43 is increased by long-term potentiation (LTP) induction in the hippocampus (for review, see Routtenburg, 1986). To our knowledge, this is the first report of NMDA receptor activation regulating phosphorylation of the five proteins we call NARPPs. Other front phosphorylation studies using hippocampal slices (Yip and Kelly, 1989), cultured hippocampal pyramidal cells (Scholz and Palfrey, 1991), or cultured cerebellar granule cells (Graham and Burgoyne, 1993) demonstrated that high potassium, glutamate, or prolonged NMDA stimulation lead to selective phosphorylation of several proteins, none of which have the properties of our NARPPs. There are many reasons why our results could differ from previous observations. First, high potassium or glutamate application probably leads to activation of many receptor types, whereas phosphorylation of NARPPs is inhibited by AP-5, indicating that NMDA receptor activation is 

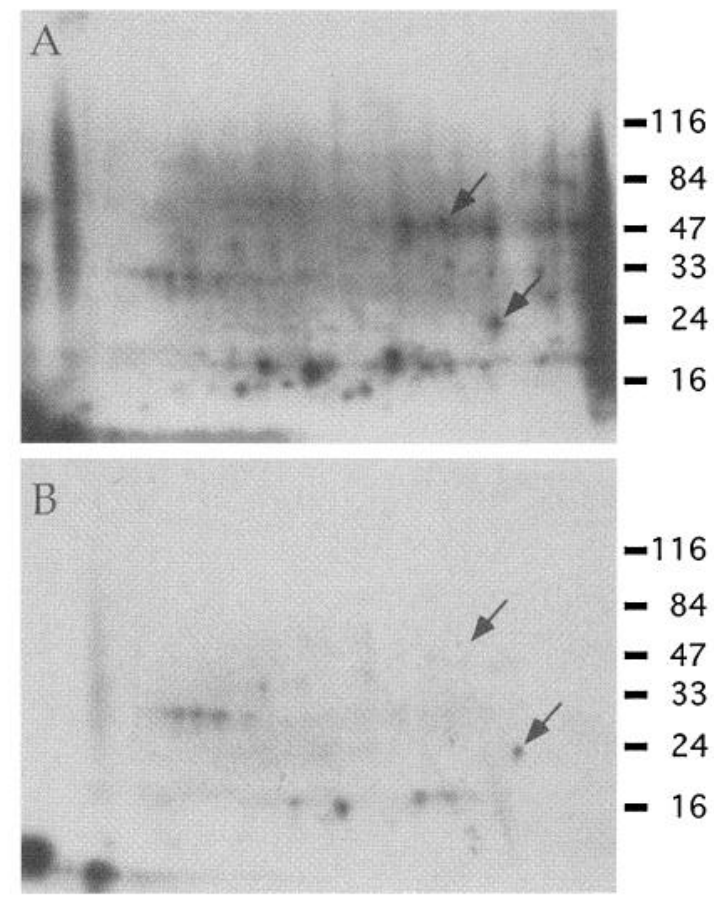

Figure 6. Stimulation of PKC in whole tecta leads to NARPP-21 and -50 phosphorylation. Tecta were loaded with radioactive phosphate as in Figure 3 and stimulated with either $100 \mathrm{~nm}$ PMA $(n=3)(A)$ or $100 \mathrm{~nm}$ $4 \alpha$ PMA $(n=3)(B)$. Arrows indicate the location of NARRP-21 and -50 . Note the presence of NARPP-21 in $B$. Also note the presence of a large number of proteins phosphorylated by PMA treatment but not by Glut + NMDA-treatment (Fig. $3 A$ )

critical. Second, although the hippocampus clearly is capable of synaptic plasticity (LTP), glutamate stimulation in slices only recently has been shown to induce this plasticity (Cormier et al., 1993), and the paradigm required to do this is quite different from that used to assay protein phosphorylation. Simple bath application is unlikely to lead to LTP. Third, and perhaps the most important, our experimental system differs in many ways from those used to study LTP. In the developing tectum there is no need to induce synaptic change; it is an ongoing event involving all the retinotectal synapses, which represent the predominant inputs to this region in frogs (Reh and Constantine-Paton, 1984). Thus, second messenger pathways involved in this plasticity must be functioning continually at a high level. Additionally, changes in synaptic function, probably the primary event in LTP, may be small compared with the NMDA receptor-linked changes in stability of neuronal processes and synaptic connections seen in the tectum. Finally, the whole excised tecta allows examination of short-duration biochemical changes in a preparation, with most of its local and tangential circuitry intact.

One study has used the advantages of the tadpole tectum model of synaptic plasticity outlined above to examine the effects of chronic kinase inhibition on in vivo phosphorylation and ocular dominance stripe desegregation (Cline and Constantine-Paton, 1990). Chronic treatment with the phorbol ester phorbol 12, 13 dibutyrate, which can downregulate PKC activity, or with sphingosine, which inhibits PKC activity, reduced retinal ganglion cell arbor size without desegregating stripes. These agents moderately reduced resting phosphorylation levels of three proteins in tecta, suggesting inhibition of kinases. These data imply that PKC is not involved in tectal stripe desegregation and therefore that

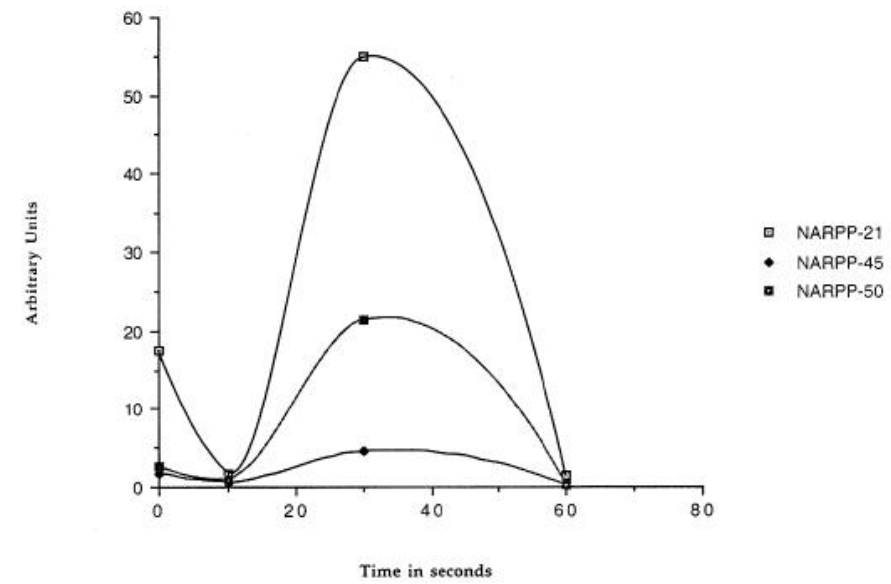

Figure 7. Time course of NARPP phosphorylation by Glut + NMDA application. Tecta were stimulated for various lengths of time, and NARPPs were detected by autoradiography of the resulting twodimensional gels. Densitometric measurement of NARPP-21 (open square with black dot), NARPP-45 (filled diamond), and NARPP-50 (filled square with white dot) phosphorylation was then performed. There was an initial reduction in NARPP phosphorylation at $10 \mathrm{sec}$ of stimulation followed by a maximum at $30 \mathrm{sec}$ of stimulation. At $1 \mathrm{~min}$ of stimulation, NARPP phosphorylation levels had returned to baseline or below. All gels for a given experiment were run in parallel and exposed to the same film. Equal amounts of radioactive protein were loaded on each gel. The results presented here are representative of three independent determinations for each time point.

NARPP-21 and -50, both PKC substrates, are not critical to retinotectal synapse stabilization. Although this interpretation is possible, it is important to note two points. First, as emphasized above, NARPP phosphorylation after acute NMDA receptor stimulation involves combined effects of dephosphorylation and phosphorylation. As suggested by Cline and Constantine-Paton (1990), chronic application of kinase inhibitors could initiate compensatory mechanisms to maintain some critical level of NARPP-21 and -50 phosphorylation, even during PKC inhibition. Second, our results do not indicate whether PKC is responsible for the net increase in NARPP-21 and -50 phosphorylation caused by NMDA receptor activation. Knowledge of the amino acid sequence of NARPP-21 and -50 and identification of other kinases capable of phosphorylating these proteins could resolve this issue.

We tried to examine the calcium dependence of NARPP phosphorylation using extracellular $\mathrm{Ca}^{2+}$ chelators, but this resulted in decreased viability of the preparation. Instead we used dantrolene, which inhibits release of calcium from $\mathrm{IP}_{3}$-sensitive intracellular stores in neurons (Belhage et al., 1992). Surprisingly, this treatment eliminated NARPP phosphorylation, which suggests that it is regulated by additive effects of NMDA receptor activation and release of calcium from $\mathrm{IP}_{3}$-sensitive calcium stores. The nature of this interaction is unclear but may involve calciumdependent calcium release (Belhage et al., 1992).

We took advantage of two observations to determine whether any NARPP was located in the postsynaptic density. First, ATP does not readily cross cell membranes, and second, in unlysed synaptosomes, the postsynaptic density is exposed to the incubation solution (Dunkely and Robinson, 1986). By phosphorylating unlysed synaptosomes with $\left[\gamma^{-32} \mathrm{P}\right] \mathrm{ATP}$, we detected NARPP-50. This finding suggests that NARPP-50 is located in the postsynaptic density, which places this protein near the plasticity-related calcium influx. 

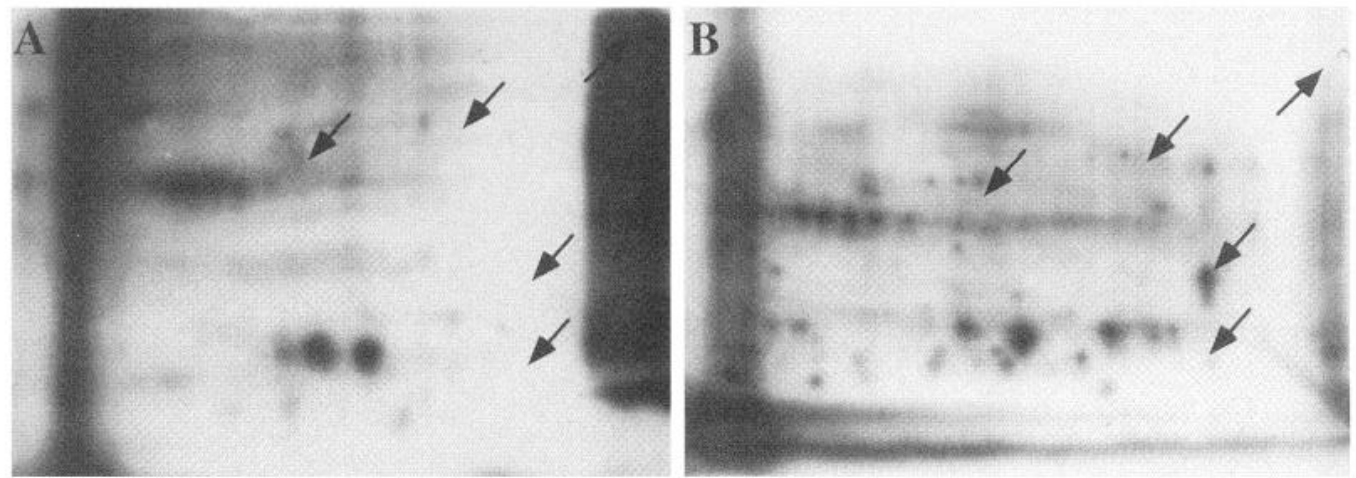

Figure 8. The effects of other stimulation on NARPP phosphorylation. $A$ shows the effects of $30 \mu \mathrm{M}$ dantrolene in the Glut + NMDA application solution $(n=4)$. Arrows point to where NARPPs should be. No NARPP phosphorylation could be detected. This procedure resulted in a massive radioactive front migrating to the acid end of the IEF gel, obscuring any possible NARPP-90 phosphorylation. $B$ shows NARPP-21 phosphorylation after a $30 \mathrm{sec}$ stimulation with $100 \mu \mathrm{M} \mathrm{t}$-ACPD $(n=3)$. The arrows point to where all NARPPs would be expected. Only NARPP-21 was observed with this stimulation.

The nuclear fraction location of NARPP-21 is also interesting. We and others have hypothesized that activation of NMDA receptors early in development affects subsequent expression of NMDA receptor subunits (Audinat et al., 1994; Bessho et al., 1994; Hofer et al., 1994; Scheetz and Constantine-Paton, 1994; Hofer and Constantine-Paton, 1994). For this to occur, neurons with NMDA receptors must be able to signal recent NMDA receptor activation to the nucleus. In addition, long-term changes

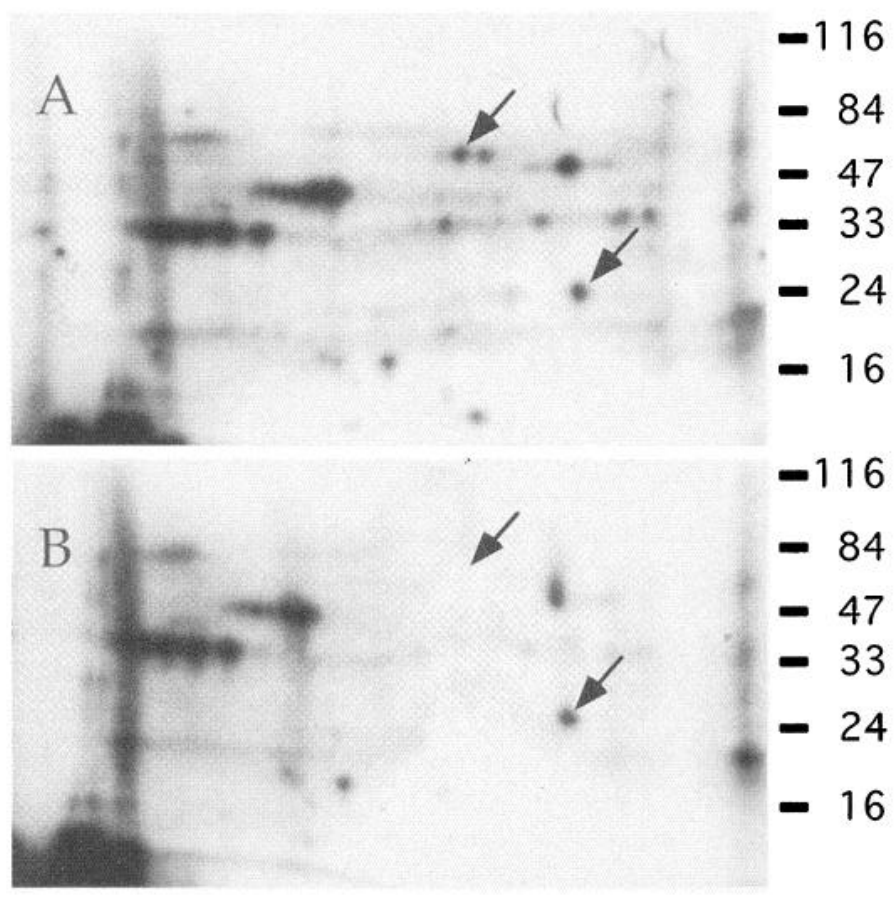

Figure 9. The effect of Glut + NMDA application on NARPP phosphorylation in mature frog tectum. $A$ shows the result of Glut + NMDA application on NARPP phosphorylation in an adult frog tectum $(n=2)$, in which synaptic rearrangement is greatly reduced compared with tadpole tecta. Arrows point to NARPP-21 and -50, both of which are responsive to Glut + NMDA application. No other NARPPs seem to be phosphorylated in this tissue. $B$ shows the effect of a $30 \mathrm{sec}$ stimulation with $10 \mu \mathrm{M}$ glutamate alone $(n=2)$. The arrows point to where NARPP-21 and -50 should be. Of the previously detected NARPPs, only NARPP-21 is phosphorylated with this stimulation in adult tecta. in synaptic function involve changes in transcription of several nonreceptor proteins (Thomas et al., 1994; Worley et al., 1994). NARPP-21 is a candidate component of these signaling processes.

The compound $\mathrm{t}$-ACPD preferentially activates metabotropic glutamate receptors that inhibit forskolin-stimulated cAMP formation (for review, see Hollman and Heinemann, 1994), but at the concentration used here, this agonist may also activate $\mathrm{IP}_{3}$ coupled metabotropic receptors (Zirpel et al., 1995). How both Glut + NMDA application and t-ACPD application increase NARPP-21 phosphorylation is unclear. Perhaps inhibition of cAMP formation activates the same kinases that phosphorylate NARPP-21 after Glut + NMDA application. Alternatively, NARPP-21 could be phosphorylated by different kinases activated by different receptors. One hundred micromolar t-ACPD is a very high concentration; under physiological conditions in the tadpole tectum, activation of both metabotropic and NMDA receptors may be required to increase NARPP-21 phosphorylation. In mature tecta, however, $10 \mu \mathrm{M}$ glutamate stimulation alone produces significant NARPP-21 phosphorylation. Perhaps in adulthood, when NMDA receptor-mediated synapse stabilization is reduced, a metabotropic glutamate receptor subtype is predominantly responsible for increasing phosphorylation of this potential nuclear signaling protein.

The identities of the NARPPs are not yet determined. Twodimensional gel Western blotting with antibodies to synapsin 2, syntaxin, ERKs 1, 2, and 3, Mek 1 and 2, neurofilaments, CaM kinase II $\alpha$ and $\beta$ subunits, and Ras were all negative. Also, GTP overlay assays show that the NARPPs are not among the class of small GTP-binding proteins that this assay detects (Huber et al., 1994). Moreover, the inability of the major calcium-dependent kinases to phosphorylate NARPP-90, -45 , and -10 may mean that more selective kinases are responsible for phosphorylation of some NARPPs. Thus, we may have detected a novel NMDA receptor-linked signal transduction pathway. In this case, further characterization of NARPPs could identify key elements in the second messenger systems involved in NMDA receptordependent synaptic plasticity.

\section{REFERENCES}

Aoki C, Siekevitz P (1985) Ontogenetic changes in the cyclic adenosine $3^{\prime}, 5^{\prime}$-monophosphate stimulatable phosphorylation of cat visual cortex proteins, particularly of microtubule-associated protein 2 (MAP 2): 
effects of normal and dark rearing and of the exposure to light. J Neurosci 5:2465-2483.

Audinat E, Lambolez B, Rossier J, Crépel F (1994) Activity-dependent regulation of $N$-methyl-D-aspartate receptor expression in rat cerebellar granule cells. Eur J Neurosci 6:1792-1800.

Belhage B, Rehder V, Hansen GH, Kater SB (1992) ${ }^{3} \mathrm{H}$-D-aspartate release from cerebellar granule neurons is differentially regulated by glutamate and $\mathrm{K}^{+}$-stimulation. J Neurosci Res 33:436-444.

Bessho Y, Nawa H, Nakanishi S (1994) Selective up-regulation of an NMDA receptor subunit mRNA in cultured cerebellar granule cells by $\mathrm{K}^{+}$-induced depolarization and NMDA treatment. Neuron 12:87-95.

Breer $H$, Jeserich $G$ (1980) A microscale flotation technique for the isolation of synaptosomes from nervous tissue of Locusta migratia. Insect Biochem 10:457-463.

Cline HT, Debski E, Constantine-Paton M (1987) NMDA receptor antagonist desegregates eye-specific stripes. Proc Natl Acad Sci USA $81: 1312-1315$.

Cline HT, Constantine-Paton M (1989) NMDA receptor antagonists disrupt the retinotectal topographic map. Neuron 3:413-426.

Cline HT, Constantine-Paton M (1990) The differential influence of protein kinase inhibitors on retinal arbor morphology and eye-specific stripes in the frog retinotectal system. Neuron 4:899-908.

Cline HT, Debski EA, Constantine-Paton M (1990) The role of the NMDA receptor in the development of the frog visual system. In: Advances in experimental medicine and biology, pp 197-203. New York: Plenum.

Constantine-Paton M (1990) NMDA receptors as mediators of activitydependent synaplogenesis in the developing brain. In: Cold Spring Harbor symposia on quantitative biology, pp 431-443. Cold Spring Harbor, NY: Cold Spring Harbor Laboratory.

Constantine-Paton M, Cline HT, Debski EA (1990) Patterned activity, synaptic convergence and the NMDA receptor in developing visual pathways. Annu Rev Neurosci 13:129-154.

Cormier RJ, Mauk MD, Kelly PT (1993) Glutamate iontophoresis induces long-term potentiation in the absence of evoked presynaptic activity. Neuron 10:907-919.

Debski EA, Constantine-Paton M (1988) The effect of glutamate receptor agonists and antagonists on the evoked tectal potential in Rana pipiens. Soc Neurosci Abstr 14:674.

Dunkely PR, Robinson PJ (1986) Depolarization-dependent protein phosphorylation in synaptosomes: mechanisms and significance. In: Phosphoproteins in neuronal function (Gispen WH, Ruttenberg A, eds), pp 273-294. Amsterdam: Elsevier.

Easter SS, Rusoff $\Lambda \mathrm{C}$, Kish PE (1981) The growth and organization of the optic nerve and tract in juvenile and adult goldfish. J Neurosci 1:793-811.

Garrison JC (1993) Study of protein phosphorylation in intact cells. In: Protein phosphorylation (Hardie DG, ed), pp 1-30. Oxford: IRL.

Gaze RM, Ketting MJ, Chung SH (1974) The evolution of the retinotectal map during development in Xenopus. Proc $\mathrm{R}$ Soc Lond [Biol] 185:301-330.

Graham ME, Burgoyne RD (1993) Phosphoproteins of cultured cerebellar granule cells and response to the differentiation-promoting stimuli NMDA, high $\mathrm{K}^{+}$and ionomycin. Eur J Neurosci 5:575-583.

Guitart X, Nestler EJ (1989) Identification of morphine- and cyclic AMP-regulated phosphoproteins (MARPPs) in the locus coeruleus and other regions of rat brain: regulation by acute and chronic morphine. J Neurosci 9:4371-4387.

Halpain SL, Greengard P (1990) Activation of NMDA receptors induces rapid dephosphorylation of the cytoskeletal protein MAP-2.' Neuron 5:237-246.

Hofer M, Constantine-Paton M (1994) Regulation of NMDA receptor function during the rearrangement of developing neural connections. Prog Brain Res 102:277-285.

Hofer M, Prusky GT, Constantine-Paton M (1994) Regulation of NMDA receptor $m R N A$ during visual map formation and after receptor blockade. J Neurochem 62:2300-2307.

Hollman M, Heinemann S (1994) Cloned glutamate receptors. Annu Rev Neurosci 17:31-108.

Huber LA, Ullrich O, Takai Y, Lutcke A, Dupree P, Olkkonen V, Virta H, de Hoop MJ, Alexandrov K, Peter M, Zerial M, Simons K (1994) Mapping of Ras-related GTP-binding proteins by GTP overlay follow ing two-dimensional gel electrophoresis. Proc Natl Acad Sci USA 91:7874- -7878 .
Kojima I, Kojima K, Kreutter D, Rasmussen H (1984) The temporal integration of the aldosterone secretory response to angiotensin occurs via two intracellular pathways. J Biol Chem 259:14448-14457.

Krebs EG, Beavo JA (1979) Phosphorylation-dephosphorylation of enzymes. Annu Rev Biochem 48:923-959.

Krueger BK, Forn J, Greengard P (1977) Depolarization-induced phosphorylation of specific proteins, mediated by calcium influx, in rat brain synaptosomes. J Biol Chem 252:2764-2773.

Kullman D, Perkel DJ, Manabe T, Nicoll RA (1992) $\mathrm{Ca}^{++}$entry via postsynaptic voltage-sensitive $\mathrm{Ca}^{++}$channels can transiently potentiate excitatory synaptic transmission in the hippocampus. Neuron 9:1175-1183.

Kuo JF, Greengard P (1970) Cyclic nucleotide-dependent protein kinases. VII. Comparison of various histones as substrates for adenosine 3',5'-monophosphate-dependent and guanosine $3^{\prime}, 5^{\prime}$-monophosphatedependent protein kinases. Biochim Biophys Acta 212:434-440.

Lee KAW, Bindereif A, Green MR (1988) A small-scale procedure for preparation of nuclear extracts that support efficient transcription and pre-mRNA splicing. Gene Anal Tech 5:22-31.

Lynch G, Larson J, Kelso S, Barrineuvo G, Schottler F (1983) Intracellular injections of EGTA block induction of hippocampal long-lerm potentiation. Nature 305:719-721.

Malenka RC, Madison DV, Nicoll RA (1986) Potentiation of synaptic transmission in the hippocampus by phorbol esters. Nature 321:175-177.

Malinow R, Madison VD, Tsien RW (1988) Persistent protein kinase activity underlying long-term potentiation. Nature 335:820-824.

Mastronarde DN (1983a) Correlated firing of cat retinal ganglion cells. I. Spontaneously active inputs to $X-$ and Y-cells. $J$ Neurophysiol 49:303-324.

Mastronarde DN (1983b) Correlated firing of cat retinal ganglion cells. II. Responses of X-and Y-cells to single quantal events. J Neurophysiol 49:325-349

Mayer ML, Westbrook GL, Guthrie PB (1984) Voltage-dependent block by $\mathrm{Mg}^{2+}$ of NMDA responses in spinal cord neurones. Nature 309:261-263.

Mitsui K, Brady M, Plafrey HC, Nairn AC (1993) Purification and char acterization of calmodulin-dependent kinase III from rabbit reticulocytes and rat pancreas. J Biol Chem 268:13422-13433.

Nairn $A C^{-}$, Hemmings $\mathrm{HC}^{-}$, Greengard $\mathrm{P}$ (1985) Protein kinases in the brain. Annu Rev Biochem 54:931-976.

Reh TA, Constantine-Paton M (1984) Retinal ganglion cell terminals change their projection sites during larval development of Rana pipiens. J Neurosci 4:442-457.

Routtenburg A (1986) Synaptic plasticity and protein kinase C. Prog Brain Res 69:211-234.

Scheetz AJ, Constantine-Paton M (1994) Modulation of NMDA receptor function: implications for vertebrate neural development. FASEB J 8:745-752.

Scholz WK, Palfrey HC (1991) Glutamate-stimulated protein phosphorylation in cultured hippocampal pyramidal neurons. $J$ Neurosci $11: 2422-2432$.

Schulman H (1991) Serine/threonine kinases in the nervous system. Curr Opin Neurobiol 1:43-52.

Taylor AC, Kollros JJ (1946) Stages in the normal development of Rana pipiers larvae. Anat Rec 94:7-23.

Thomas KL, Laroche S, Errington ML, Bliss TVP, Hunt SP (1994) Spatial and temporal changes in signal transduction pathways during LTP. Neuron 13:737-745.

Udin SB, Fawcett JW (1988) Formation of topographic maps. Annu Rev Neurosci 11:289-327.

Udin SB, Scherer WJ, Constantine-Paton M (1992) Physiological effects of chronic and acute application of $N$-methyl-D-aspartate and 5-aminophosphonovalcric acid to the optic tectum of Rana pipiens frogs. Neuroscience $49: 739-747$.

Worley PF, Bhat RV, Baraban JM, Erickson CA, McNaughton BL, Barnes CA (1994) Thresholds for synaptic activation of transcription factors in hippocampus: correlation with long-term enhancement. J Neurosci 13:4776-4786.

Yip RK, Kelly PT (1989) In situ protein phosphorylation in hippocampal slices. J Neurosci 9:3618-3630.

Zirpel L, Lachica EA, Rubel EW (1995) Activation of a metabotropic glutamate receptor increases intracellular calcium concentrations in neurons of the avian cochlear nucleus. J Neurosci 15:214-222. 